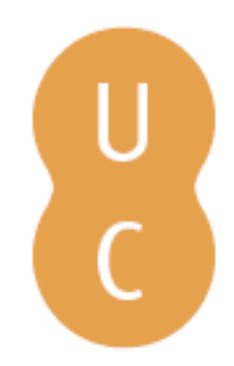

\title{
pompalina
}

\section{Critical conditions for the ignition of cedar needle fuel bed as a result of firebrands accumulation}

\author{
Autor(es): \\ Kasymov, \\ D. P.; Agafontsev, M \\ A. I. \\ Publicado por: Imprensa da Universidade de Coimbra \\ URL \\ persistente: \\ URI:http://hdl.handle.net/10316.2/44690 \\ DOI: \\ DOI:https://doi.org/10.14195/978-989-26-16-506_173 \\ Accessed : $\quad$ 26-Apr-2023 02:12:32
}

A navegação consulta e descarregamento dos títulos inseridos nas Bibliotecas Digitais UC Digitalis, UC Pombalina e UC Impactum, pressupõem a aceitação plena e sem reservas dos Termos e Condições de Uso destas Bibliotecas Digitais, disponíveis em https://digitalis.uc.pt/pt-pt/termos.

Conforme exposto nos referidos Termos e Condições de Uso, o descarregamento de títulos de acesso restrito requer uma licença válida de autorização devendo o utilizador aceder ao(s) documento(s) a partir de um endereço de IP da instituição detentora da supramencionada licença.

Ao utilizador é apenas permitido o descarregamento para uso pessoal, pelo que o emprego do(s) título(s) descarregado(s) para outro fim, designadamente comercial, carece de autorização do respetivo autor ou editor da obra.

Na medida em que todas as obras da UC Digitalis se encontram protegidas pelo Código do Direito de Autor e Direitos Conexos e demais legislação aplicável, toda a cópia, parcial ou total, deste documento, nos casos em que é legalmente admitida, deverá conter ou fazer-se acompanhar por este aviso.

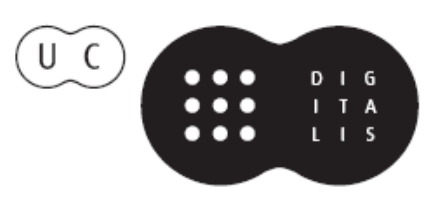




\section{ADVANCES IN}

\section{FOREST FIRE RESEARCH}

\section{8}

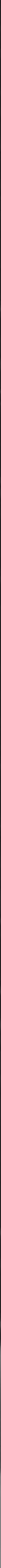


Short contribution - Fire at the Wildland Urban Interface

Critical conditions for the ignition of cedar needle fuel bed as a result of firebrands accumulation

\author{
D. P. Kasymov ${ }^{1 *}$, M. V. Agafontsev¹, V. N. Fateev ${ }^{1}$, V. V. Reyno ${ }^{2}$, A. I. Filkov ${ }^{3}$ \\ ${ }^{I}$ National Research Tomsk State University, Tomsk, Russia, \{denkasymov@ gmail.com*\} \\ ${ }^{2}$ V.E. Zuev Institute of Atmospheric Optics SB RAS, Tomsk, Russia, \{reyno@iao.ru\} \\ ${ }^{3}$ University of Melbourne, School of Ecosystem and Forest Sciences, Melbourne, Australia, \\ \{alexander.filkov@unimelb.edu.au\}
}

Keywords: glowing firebrands, accumulation, spotting, critical conditions, ignition time

\title{
1. Introduction
}

It is well known that flaming and glowing particles are a major cause of wildland and wildlandurban interface fires (Cohen 2000; Caton et al. 2017). In recent years, many papers devoted to this problem have studied firebrands trajectory in the airflow, their transportation distance (Ellis 2000; Anthenien et al. 2006; Kortas et al. 2009; Song et al. 2017) and evaluated firebrands ability to ignite fuel beds(Manzello et al. 2008; Filkov et al. 2016; Kasymov et al. 2016; Fateev et al. 2017). However, the problem still requires further research, as, in particular, critical conditions for the ignition of the fuel bed as a result of firebrands accumulation depending on their size, shape and ambient conditions remain largely unknown.

It should be noted that the interaction of flaming (burning) and glowing particles with the fuel bed is a complex process, which requires both theoretical and experimental approaches. The earlier papers demonstrated that flaming particles ignite the fuel bed more easily; for this reason, our research has been focused on glowing particles.

As was shown in(El Houssami et al. 2016), during surface fires tree bark and twigs turn into glowing particles. Therefore, the aim of the present work is to study accumulation of glowing twigs of various sizes and their interaction with forest fuel beds. In particular, the paper studied fuel bed ignition time, flaming and smouldering duration times and the heat flux critical value sufficient to ignite the fuel bed.

\section{Methods and Results}

An experimental setup was created which permitted to simulate firebrands accumulation with a controlled number of firebrands being dropped and which in turn allowed to evaluate their effect on the fuel bed (fig. 1).
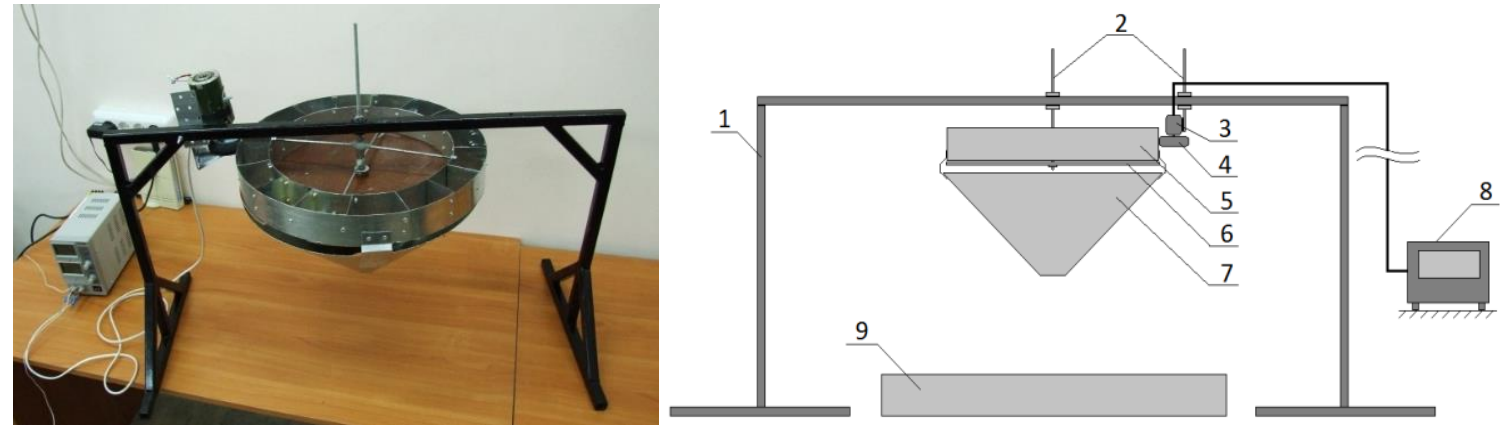

Figure1 - Experimental setup to simulate firebrand accumulation on the fuel bed: 1 - rack; 2 -adjusting bolts; 3 electric motor; 4 -driving wheel; 5 -box; 6 -disk-separator; 7 -funnel; 8 -adjustable power supply; 9 -tray 
Birch tree cylindrical samples with diameters of $6 \mathrm{~mm}, 8 \mathrm{~mm}, 10 \mathrm{~mm}, 12 \mathrm{~mm}, 14 \mathrm{~mm}$ and $50 \mathrm{~mm}$ in length were used as firebrands (fig.2).

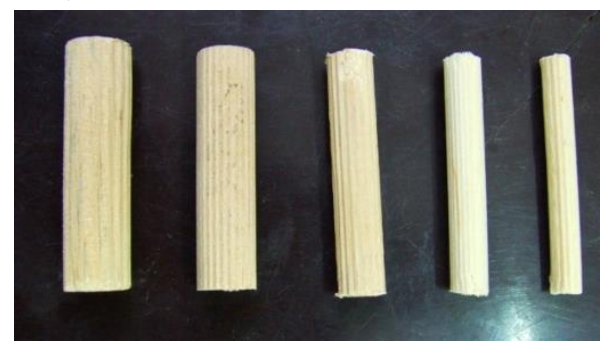

Figure 2 - Firebrand samples

The moisture content was determined using the AND MX-50 moisture analyser. The firebrands moisture content and the fuel bed (cedar needles) were $4.2 \pm 0.2 \%$ and $6 \pm 0.2 \%$ respectively. A thermal imaging camera JADE J530SB and a video camera Canon HF R88 were used to evaluate the firebrands temperature and to record the experiment. Three repetitions were performed for each experiment, three successful or unsuccessful ignitions in a row. In case of one or two ignitions, the number of experiments was increased to reach at least three ignitions for statistical analysis.

The following procedure was used for the experiment: cedar needles were placed on the tray (9) to simulate a fuel bed with a density of $56 \mathrm{~kg} / \mathrm{m}^{3}$; firebrands were put into the box (5) and heated with gas burners until they began to glow while the whole process was controlled with the thermal imaging camera. The frequency of firebrands drops on the tray (9) was regulated by changing the electric motor rotation speed (3). The precision of firebrands drops was regulated by adjusting the height of the setup over the fuel bed using adjusting bolts (2) and funnel (7). The experiment started with dropping one particle every 4 seconds until reaching a total of 10 particles. If the fuel bed was ignited, fresh cedar needles were put on the tray (9). Three repetitions were carried out for each experiment. Fuel bed ignition was defined as a moment when a flame appeared over the fuel bed, which was recorded with a video camera. Fuel bed smouldering was defined as continuous uninterrupted smouldering caused by firebrands and which lasted for $5 \mathrm{~min}$.

A preliminary series of experiments was carried out in the absence of wind and with wind speed of $1.5 \mathrm{~m} / \mathrm{s}$ with firebrands $50 \mathrm{~mm}$ long and with diameters of $6 \mathrm{~mm}$ and $8 \mathrm{~mm}$. Under the chosen experimental parameters in the absence of wind fuel bed ignition did not occur except on a few occasions when fuel bed smouldering was initiated and lasted for $3 \mathrm{~min}$ after the firebrands had stopped burning. With the wind speed of $1.5 \mathrm{~m} / \mathrm{s}$, the fuel bed ignition was observed and was started by eight $6 \mathrm{~mm}$ particles, or by six $8 \mathrm{~mm}$ particles, i.e. an increase in the firebrands diameter led to a decrease of the number of firebrands required ignition to occur.

During the next experimental stage, particles with diameters of $10 \mathrm{~mm}, 12 \mathrm{~mm}$ and $14 \mathrm{~mm}$ and the wind speed of $1-1.5 \mathrm{~m} / \mathrm{s}$ will be used to evaluate both the probability of ignition depending on the number of particles and the critical heat flux produced by them.

\section{Acknowledgements}

This study was supported by the Russian Foundation for Basic Research (project No. 18-07-00548).

\section{References}

Anthenien RA, Tse SD, Carlos Fernandez-Pello A (2006) On the trajectories of embers initially elevated or lofted by small scale ground fire plumes in high winds. Fire Safety Journal 41, 349 363. doi:10.1016/j.firesaf.2006.01.005. 
Caton SE, Hakes Raquel SP, Gorham DJ, Zhou A, Gollner MJ (2017) Review of Pathways for Building Fire Spread in the Wildland Urban Interface Part I: Exposure Conditions. Fire Technology 53, 429-473. doi:10.1007/s10694-016-0589-z.

Cohen JD (2000) What is the Wildland Fire Threat to Homes? https://www.fs.fed.us/rm/pubs_other/rmrs_2000_cohen_j003.pdf.

Ellis PF (2000) The aerodynamic and combustion characteristics of eucalypt bark - a firebrand study. Ph.D. Dissertation, Australian National University, Canberra.

Fateev V, Agafontsev M, Volkov S, Filkov A (2017) Determination of smoldering time and thermal characteristics of firebrandsunder laboratory conditions. Fire Safety Journal 91, 791-799.

Filkov AI, Kasymov DP, Zima VP, Matvienko OV (2016) Experimental investigation of surface litter ignition by bark firebrands. In 'AIP Conf. Proc. 1698', 060004

El Houssami M, Mueller E, Filkov A, Thomas JC, Skowronski N, Gallagher MR, Clark K, Kremens R, Simeoni A (2016) Experimental Procedures Characterising Firebrand Generation in Wildland Fires. Fire Technology 52, doi:10.1007/s10694-015-0492-z.

Kasymov DP, Filkov AI, Baydarov DA, Sharypov OV (2016) Interaction of smoldering branches and pine bark firebrands with fuel bed at different ambient conditions. In 'Proc. SPIE 10035', 100356H doi:10.1117/12.2249083.

Kortas S, Mindykowski P, Consalvi J, Mhiri H, Porterie B (2009) Experimental validation of a numerical model for the transport of firebrands. Fire Safety Journal 44, 1095-1102. doi:10.1016/J.FIRE SAF.2009.08.001.

Manzello SL, Cleary TG, Shields JR, Maranghides A, Mell W, Yang JC (2008) Experimental investigation of firebrands: Generation and ignition of fuel beds. Fire Safety Journal 43, 226-233. doi:10.1016/j.firesaf.2006.06.010.

Song J, Huang X, Liu N, Li H, Zhang L (2017) The wind effect on the transport and burning of firebrands. Fire Technology 1-14. doi:10.1007/s10694-017-0647-1. 